\title{
Opportunity and Challenge of Human Resource Development and Saving Behavior Adaptation of Older Persons in Thai Society.
}

\author{
PetprakaiKultangwattana* \\ Students ProgramsDoctor ofPublic Administration. BuraphaUniversity. \\ petprakai@gmail.com
}

\begin{abstract}
Introduction of preparation on Human Resource Development for Older Persons of Thailand. The direction of human resource preparation should be compatible with the country's future human resource preparation starting from young-age population through old-age population with human resource development plan in short-term and long-term. By every population would be ready for financial survival in old-age period leading to good quality and independent basic life. The government can reduce budget on the care of older persons as people decreasingly depend on the government. In addition, those human resource developments can be prepared people moving forwards to old-age way of life. The government can create collaboration through family institute in order to make it participate in preparation of money saving behavior as family institute is the first social institution of people. Family institute acts as the role model on good behavior and also through its socialization leading to human resource development on skill and discipline of money spending and saving in daily life including learning stimulation.
\end{abstract}

Keywords: Human Resource Development, Saving Behavior Adaptation, Older Persons, Thai Society

\section{Introduction}

All populations are valuable resources for country development. As older persons have more knowledge and experience than other ages and also contribute to the country's economic stability and growth by paying tax to the government during their working-age period. However, the tax contribution from older persons, who have no work, is not enough comparing to working-age populations. Nowadays, Thailand is facing the problem of moving forwards to ageing society as the proportions of older persons sharply increase around $11.9 \%$ from theyear 2012 and forecasting to increase their older populations more than 2 times or $25 \%$ of total populations in 10 years onwards. It can be defined as perfect ageing society. However, working-age populations that support the older persons have decrease from the year 2012. The average of 6 working-age populations that taking care of one older person will be decreasing to only 2 working-age populations per one older person in 2022 leading to more duties of working-age populations to take care of the older persons. ${ }^{1}$
${ }^{1}$ Promotion and Protection of the Elderly 2014

According to this situation, Thai society has been changed from extended family to single family in which working-age populations have no ability to take care of the older persons. Accordingly, the government has to pay attention to the care of older person as they have been contributed to the country's development, created benefits and income through huge tax payment to the country. Consequently, the Act on Older Persons B.E. 2546 (2003 A.D.) has been announced with the following notifications; the right of older persons on tax exemption, the national pension system development, the provident fund establishment for older persons, the extensive provision of accommodation provided for older persons, the payment of monies for older persons, and the free medical and public health services for older persons.

The principal plans for older persons undertaken by the government have been spent on its budget more than 100,000 million ${ }^{2}$ baht per year. In addition, there will be continuing increase in the care of older persons' budget spending in 2030 as 
average life expectancy of populations increase from 65 years old to 72 years old. ${ }^{3}$ One of many reasons on the increase in life expectancy is medical technology advancement of the country reflecting the care of human resources through welfare promotion for older persons. However, the country will be faced with welfare promotion services for older persons. ${ }^{4}$

Even the government supports the care of human resources especially for older persons, the limitation of the care and human resource development the lack of preparation for money saving for old-age spending starting from youngage period through working-age period. $51 \%$ of totalpopulations have not enough money saving for old-age period. The older persons depend on the government through working-age tax contribution to the country ${ }^{5}$ as they lack of knowledge on money saving for old-age spending. They have not enough money to survive during their old-age period because the lack of preparation on learning and creating social value of money saving during young-age period, working-age period through old-age period, etc. ${ }^{6}$ However, long-term

human resource development plan for survival in every age has been established in developed country such as

\footnotetext{
${ }^{2}$ Office of National Statistics. 2013

${ }^{3}$ Promotion and Protection of the elderly.2014

${ }^{4}$ Office of National Statistics. 2013
}

${ }^{5}$ Office of National Statistics. 2013

\section{${ }^{6}$ Banroot Siriphanich.2014}

human resource development through continuous learning on money saving from young-age period, working-age period, and old-age period and social value creation on money saving in all ages. Collaboration among public sector, private sector and civil society would be creating in order to continuehuman resource development on money saving in every age.

Therefore, researcher is interested in analysis of opportunity and challenge of human resource development and saving behavior adaptation of older persons in Thai society

\section{Preparation on Human Resource \\ Development For Older Persons Of Thailand}

The direction of human resource preparation should be compatible with the country's future human resource preparation starting from youngage population through old-age population with human resource development plan in short-term and long-term. Educational system design in all levels of the society and social value creation of necessary skills on money saving should be promoted; for examples, critical thinking and problem solving skill developments, creativity and innovation skills, cross-cultural understanding skill, collaboration, teamwork and leadership skills, communications, information and media literacy skills, computing andinformation communication and technologyICT literacy skills, and career and learning skills. 
Figure 1: Modelof Preparation on Human Resource Development for Older Persons of Thailand

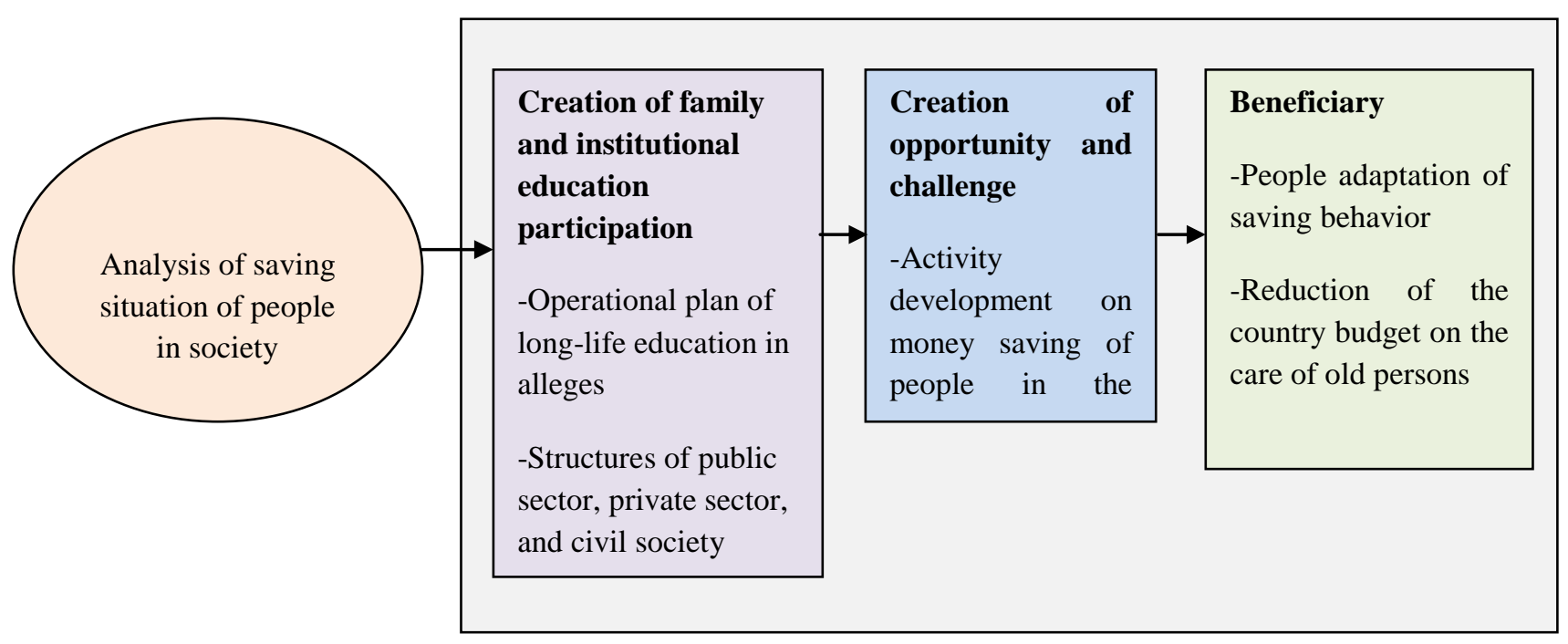


According to Figure 1, this modelof Preparation on Human Resource Development for Older Persons of Thailand show that the opportunity and challenge of human resource development on moneysaving of country's people need to be analyzed the saving situation in the society in order to use as input for human resource planning and preparation of saving through educational systems starting from young-age, working-age, and old-age period. Public sector, private sector, and civil society will be contributing to create long-life education operational plan on money saving for all populations in the country and also their structures. In addition, the government needs to establish enhancement activities on money saving for alleges and enact the law enforcement on saving of all people. The government should support research on factors influencing money saving behaviors in allages including control and monitoring of law enforcement on saving of all ages. Operational plan on human resource preparation need to be evaluating on effectiveness, which is designed in compatible with the national strategic plan on human resource preparation on saving in every age. If the government performs in accordance with the plan, it would be reflect on saving behavior of the country's population leading to saving culture creation and also reduction on government budget for the care of older persons in long-term.

According to the guideline on human resource preparation, every population would be ready for financial survival in old-age period leading to good quality and independent basic life. Accordingly, the government can reduce budget on the care of older persons as people decreasingly depend on the government. In addition, those human resource developments can be prepared people moving forwards to old-age way of life. The government can create collaboration through family institute in order to make it participate in preparation of money saving behavior as family institute is the first social institution of people. Family institute acts as the role model on good behavior and also through its socialization leading to human resource development on skill and discipline of money spending and saving in daily life including learning stimulation. Parents should be trained by the public agency in order to be the role model on money spending and saving in daily life. Parents can pass discipline on money spending and saving to teachers in school to acts as the role model of students as they leave in school around 7-8 hours a day on average. Therefore, teachers in school can participate in human resource development on money saving and spending of students. Teachers in school can create atmosphere of skill distribution necessary on money spending and saving such as critical thinking and problem solving skills, creativity and innovation skills, cross-cultural understanding skill, collaboration, teamwork and leadershipskills,communications, information and media literacy skills, computing and information, communication and technology -ICT literacy skills, career and learning skills. ${ }^{7}$

In conclusion, various situations in the society are important to human resource development guideline in the country. If scholars and leaders in the country analyze these situations and create opportunity and challenge on human resource development in each aspect, people would be well-preparing for moving the way of life in the future. 


\section{Acknowledgements}

I would like to express my sincere thanks to my article advisor, Ass.prof. Dr.PattchaneTarasena for her invaluable help and constant encouragement throughout the course of this article. I am most grateful for her teaching and adviceIn addition, I am grateful for the teachers of Human Resource DevelopmentDr.Rungrungsee Vibulchai, DrPetmanee Viriyasuebphong, Dr.PetcharatViriyasuebphong, Dr.PaniteeKarnsomdee, and others person for suggestions and all their help.Finally, I most gratefully acknowledge my parents and my friends for all their support throughout the period of this article.

\section{References}

1. Population Projection Working Group.2012. Population Projection for Thailand,20102040.Bangkok:Office of theNational Economics and Social Development Board.

2. Thailand Development Research Institute.2008.A study of impacts of retirement age extension in the Publics ector. Presented to Office of thePermanent Secretary for Labor. A 2008.gust

3. Foundation of Thai Gerontology Research and Development Institute.2007. Situation of the Thai Elderly 2006. Bangkok: DuantulaPublishing

4. Foundation of Thai Gerontology Research and Development Institute.2013Quality of Life for the Elderly Program: Models and Key Factors Development of the Thai Elderly 2013. Bangkok :Duantula Publishing.

5. Rukchanok Karcharnubarn and Pataporn Sukontamarn. A Study of the Elderly Fund Management Model and Guidelines to Increase Participation.
6. National Statistical Office. The Survey of Elderly in Thailand during 1994-2011.

7. Bureau of Personnel Research and Development, Office of the Civil Service Comission.2007 Improving Retirement System.

8.Knodel,J.,Chayovan, $\mathrm{N}$ and Prachuabmoh,V2013.The Changing Well-being of Thai Elderly: An update From the 2011 Survey of Older Persons in Thailand. Help Age International 